\title{
SUPLEMENTASI CHITOSAN DERIVAT KARAPAS UDANG TERHADAP PERTUMBUHAN DAN KADAR TOTAL KOLESTEROL DARAH PADA ITIK LOKAL
}

\author{
(Supplementation of Chitosan as the Shrimp Shell Derivatives In rations on Growth and Blood Total \\ Cholesterol Levels in Local Duck)
}

\section{Pretti Sitompul ${ }^{1}$, Ma'ruf Tafsin ${ }^{2}$ dan Sayed Umar ${ }^{2}$}

1. Mahasiswa Program Studi Peternakan Fakultas Pertanian Universitas Sumatera Utara

2. Staf Pengajar Program Studi Peternakan Fakultas Pertanian Universitas Sumatera Utara

\begin{abstract}
High levels of total cholesterol be a limiting factor that causes freely against the consumption of meat and duck eggs by peoples. For it was conducted a study in May-September 2015 to observe the supplementation effect of chitosan from shrimp shell in the diet on growth and total cholesterol levels in the blood of ducks using a completely randomized design with 4 treatments and 5 replications. The treatments consisted of $T 0=$ basal diet $+0 \%$ chitosan; $T 1=$ basal diet $+9,05 \%$ powders of shrimp shell; $T 2=$ basal diet $+1,5 \%$ chitosan derivatives of shrimp shell; $T 3=$ basal diet $+1,5 \%$ chitosan by BIOTECH SURINDO. The variables were consist of feed intake, body weight gain, feed conversion ratio and total blood cholesterol levels. The results showed that supplementation of shrimp shell's powder, chitosan from shrimp shell and commercial chitosan in the diet decreased the total of blood cholesterol levels and growth performances in local ducks $(P<0.05)$. The total blood cholesterol (mg/dL) on T1; T2; T3; T4 were 252,4; 224; 153; 183. While average weekly body gain also decreased 6,55\%; 22,18\%; dan 14,02\% than control. It is concluded that suplementation of 1,5\% chitosan from shrimp shell show the best result according to the total blood cholesterol and growth performances of duck.
\end{abstract}

Keywords: Chitosan, shrimp shell, the total blood cholesterol of local duck.

\begin{abstract}
ABSTRAK
Kadar total kolesterol yang tinggi menjadi faktor pembatas yang menyebabkan konsumsi secara bebas terhadap daging maupun telur itik dihindari oleh masyarakat. Untuk itu telah dilakukan suatu penelitian pada Mei - September 2015 untuk mengamati suplementasi chitosan derivat karapas udang di dalam ransum terhadap pertumbuhan dan kadar total kolesterol darah pada itik lokal menggunakan rancangan acak lengkap dengan 4 perlakuan dan 5 ulangan. Keempat perlakuan terdiri atas $\mathrm{T} 0=$ ransum basal tanpa suplementasi; $\mathrm{T} 1=$ ransum basal $+9,05 \%$ tepung karapas udang; $\mathrm{T} 2=$ ransum basal $+1,5 \%$ chitosan derivat karapas udang; $\mathrm{T} 3=$ ransum basal $+1,5 \%$ chitosan Biotech Surindo. Peubah yang diteliti terdiri atas konsumsi ransum, pertambahan bobot badan, konversi ransum dan kadar total kolesterol darah. Hasil penelitian menunjukkan bahwa suplementasi tepung karapas udang, chitosan derivat karapas udang maupun chitosan komersial di dalam ransum dapat menurunkan kadar total kolesterol darah dan performans itik $(\mathrm{P}<0.05)$. Total kolesterol darah $(\mathrm{mg} / \mathrm{dL})$ pada perlakuan T1; T2: T3; T4 adalah 252,4; 224; 153; 185,4. Sedangkan rata-rata pertambahan bobot badan menurun $6,55 \% ; 22,18 \%$; dan 14,02\% dibandingkan terhadap perlakuan kontrol. Hasil terbaik diperoleh pada suplementasi $1,5 \%$ chitosan derivat karapas udang.
\end{abstract}

Kata kunci: Chitosan, karapas udang, kadar total kolesterol darah itik. 


\section{PENDAHULUAN}

Tingginya kadar lemak dan kolesterol di dalam produk itik masih menjadi faktor pembatas yang membuat masyarakat menghindari untuk mengkonsumsinya terlalu banyak atau terlalu sering. Ariyani (2006) menyebutkan bahwa kadar total kolesterol darah itik adalah 243-257 mg/dl. Menurut Saidin (2000) angka ini telah melebihi batas anjuran kadar kolesterol bahan makanan yang dapat dikonsumsi, yaitu maksimal 200 mg/dl.

Pemahaman mengenai prekursor-prekursor penting serta proses-proses yang terjadi di dalam biosintesa kolesterol pada tubuh itik sehingga dapat dilakukan suatu modifikasi dengan cara menambahkan suatu zat tertentu yang dapat mempengaruhi rantai biosintesa tersebut. Proses biosintesis kolesterol menghasilkan suatu produk metabolik berupa asam empedu yang merupakan prekursor utama yang diperlukan untuk mencerna lemak. Asam-asam empedu tersebut memiliki muatan negatif dan secara terus menerus akan diproduksi melalui sintesa kolesterol yang tersimpan di dalam hati. Produksi tersebut akan semakin meningkat apabila asam empedu semakin banyak diperlukan di dalam saluran pencernaan dalam usus halus (Purnamawati, 1997). Keadaan ini dapat dimanfaatkan sebagai strategi pengendalian kadar total kolesterol pada tubuh itik. Untuk mengikat muatan negatif pada asam empedu, diperlukan suatu molekul yang bermuatan positif sehingga ikatan yang terbentuk membuat reaksi muatan negatif menjadi statis.

Chitosan merupakan salah satu jenis polisakarida yang memiliki gugus bermuatan positif sehingga dapat digunakan sebagai antilipemika karena dapat berikatan dengan gugus negatif seperti asam empedu (Tjay, 2007). Chitosan merupakan produk deasetilasi chitin yang banyak ditemukan pada eksoskeleton dan kulit crustacea, salah satunya adalah karapas udang.

Chitosan terdiri dari amino polisakarida yang telah kehilangan gugus asetil sehingga memiliki muatan positif yang mampu berikatan dengan molekul bermuatan negatif seperti lemak dan asam empedu yang merupakan salah satu prekursor penting dalam sintesa kolesterol pada tubuh itik. Telah banyak dilakukan penelitian untuk menguji kemampuan chitosan dalam menurunkan kadar kolesterol, baik secara in vitro maupun in vivo.

\section{BAHAN DAN METODE PENELITIAN}

\section{Bahan}

Bahan-bahan yang digunakan adalah tepung karapas udang, chitosan derivat karapas udang serta chitosan komersial Biotech Surindo yang akan disuplementasikan ke dalam 
ransum itik sebagai perlakuan; ransum basal jenis BR.2.A $202 \mathrm{C}$ bentuk butiran; itik mojosari jantan umur satu bulan sebanyak 40 ekor sebagai media uji secara in-vivo.

Alat

Alat-alat yang digunakan adalah kandang sebagai tempat petak percobaan sebanyak 20 unit; peralatan kandang; lampu pijar 60 watt sebanyak 3 unit sebagai penerang dan pemanas; termometer ruangan; timbangan digital serta alat tulis.

\section{Metode Pelaksanaan}

Sebanyak 40 ekor itik ditempatkan secara acak ke dalam 20 petak percobaan yang masing-masing berukuran PxLxt $\left(50 \times 50 \times 70 \mathrm{~cm}^{3}\right)$ yang disusun dalam empat rangkaian paralel ke dalam suatu kandang yang telah difumigasi menggunakan formaldehyd. Setiap petak diisi oleh dua ekor itik sebagai satuan percobaan. Ransum yang digunakan adalah ransum basal jenis BR.2.A $202 \mathrm{C}$ bentuk butiran yang dibedakan menjadi empat macam perlakuan dan diulang sebanyak lima kali.

Keempat macam ransum perlakuan terdiri atas:

T0 : Ransum basal tanpa suplementasi

T1 : Ransum basal + tepung karapas udang 9,05\%

T2 : Ransum basal + chitosan karapas udang 1,5\%

T3 : Ransum basal + chitosan Biotech Surindo 1,5\%

Komposisi nutrisi ransum perlakuan dapat dilihat pada Tabel 1.

Tabel 1. Komposisi nutrisi ransum standar yang digunakan dalam penelitian.

\begin{tabular}{lcccc}
\hline \multirow{2}{*}{ Zat Nutrisi } & \multicolumn{4}{c}{ Komposisi dalam ransum } \\
\cline { 2 - 5 } & T0 & T1 & T2 & T3 \\
\hline Protein kasar (\%) & 19 & 19 & 19 & 19 \\
Serat kasar (\%) & 5 & 5 & 5 & 5 \\
Lemak (\%) & 7 & 7 & 7 & 7 \\
Air (\%) & 13 & 13 & 13 & 13 \\
Abu (\%) & 7 & 7 & 7 & 7 \\
Kalsium (\%) & 1,1 & 1,1 & 1,1 & 1,1 \\
Phospor (\%) & 0,8 & 0,8 & 0,8 & 0,8 \\
Tepung karapas udang (\%) & - & 9,05 & - & - \\
Chitosan & - & - & $1,5^{*}$ & $1,5^{* *}$ \\
\hline
\end{tabular}

(Ket : *Chitosan derivat karapas udang; **Chitosan komersial Biotech Surindo.)

\section{Parameter Yang Diamati}

\section{Konsumsi Ransum (Average Weekly Feed Intake /AWFI)}

Penentuan jumlah AWFI dilakukan dengan menghitung selisih jumlah pakan yang diberikan terhadap jumlah pakan sisa dan pakan terbuang (Purba dan Ketaren, 2011).

\section{Pertambahan Bobot Badan (Average Weekly Body Gain /AWG)}


Penentuan AWG dilakukan dengan menghitung selisih bobot penimbangan yang terbaru dilakukan terhadap bobot penimbangan minggu sebelumnya (Muhammad et al., 2014).

\section{Konversi Ransum (Feed Conversion Ratio/ FCR)}

Nilai FCR ditentukan dengan menghitung rasio perbandingan antara AWG terhadap jumlah AWFI (Purba dan Ketaren, 2011).

4. Kadar Total Kolesterol Darah

Kadar total kolesterol darah ditentukan melalui uji laboratorium menggunakan metode Cholesterol Oxidase-Peroxidase Aminoantipyrine Phenol (CHOD-PAP) yang dibaca dengan spectofotometer (Dedi dan Rachmat, 2011).

\section{HASIL DAN PEMBAHASAN}

Hasil pengukuran parameter pada suplementasi chitosan derivat karapas udang terhadap pertumbuhan itik berupa konsumsi ransum (Average Weekly Feed Intake /AWFI), pertambahan bobot badan (Average Weekly Body Gain /AWG) dan konversi ransum (feed conversion ratio /FCR) untuk masing-masing perlakuan dapat dilihat pada Tabel 2.

Tabel 2. Rata-rata konsumsi ransum, pertambahan bobot badan dan konversi ransum pada itik yang diberi ransum bersuplementasi chitosan selama 8 minggu penelitian

\begin{tabular}{cccc}
\hline \multirow{3}{*}{ Perlakuan } & \multicolumn{3}{c}{ Parameter } \\
\cline { 2 - 4 } & $\begin{array}{c}\text { Konsumsi Ransum } \pm \text { SD } \\
(\text { gram/ ekor/ minggu })\end{array}$ & $\begin{array}{c}\text { PBB } \pm \text { SD } \\
(\text { gram/ ekor/ minggu })\end{array}$ & Konversi Ransum \pm SD \\
\hline T0 & $928,06^{\mathbf{a}} \pm 4,95$ & $120,63^{\mathbf{a}} \pm 4,16$ & $7,70^{\mathbf{d}} \pm 0,24$ \\
T1 & $923,13^{\mathbf{a b}} \pm 3,67$ & $112,73^{\mathbf{b}} \pm 3,53$ & $8,20^{\mathbf{c}} \pm 0,25$ \\
T2 & $921,59^{\mathbf{b}} \pm 4,14$ & $93,89^{\mathbf{d}} \pm 1,90$ & $9,82^{\mathbf{a}} \pm 0,17$ \\
T3 & $919,28^{\mathbf{b}} \pm 4,87$ & $103,73^{\mathbf{c}} \pm 6,23$ & $8,89^{\mathbf{b}} \pm 0,54$ \\
\hline
\end{tabular}

Ket : Angka yang diikuti oleh superskrip dengan notasi berbeda ke arah vertikal menunjukkan perbedaan nyata pada uji duncan $(\mathrm{P}<0.05)$.

\section{Konsumsi Ransum (Average Weekly Feed Intake/ AWFI)}

Berdasarkan Tabel 2 rataan tertinggi konsumsi ransum terdapat pada T0 yang merupakan pakan tanpa suplementasi, yaitu 928,06 gram/ekor; diikuti oleh perlakuan T1 yang merupakan pakan dengan suplementasi 9.05\% karapas udang, yaitu 923,13 gram/ekor; diikuti oleh perlakuan T3 yang merupakan pakan dengan suplementasi 1.5\% chitosan Biotech Surindo, yaitu 921,59 gram/ekor; dan diikuti oleh perlakuan T2 yang merupakan pakan dengan suplementasi 1.5\% chitosan derivat karapas udang, yaitu 919,28 gram/ekor. 
Analisis ragam menunjukkan bahwa penambahan chitosan karapas udang di dalam ransum memberikan pengaruh yang berbeda nyata $(\mathrm{P}<0.05)$ terhadap konsumsi ransum itik, sedangkan berdasarkan hasil uji jarak berganda Duncan (Duncan's Multiple Range Test) pada tingkat signifikan 5\%, T0 merupakan perlakuan dengan konsumsi harian yang nyata tertinggi $(\mathrm{P}<0.05)$ dibandingkan T1, T3 maupun T2. Hal ini dikarenakan karapas udang mengandung kadar serat kasar berupa chitin yang tinggi antara 20-30\%, dan $72-75 \%$ dari kadar tersebut masih terdapat di dalam karapas setelah dimurnikan menjadi chitin maupun chitosan. Kandungan serat kasar yang tinggi di dalam ransum menyebabkan daya cerna menurun sehingga terasa kenyang lebih lama dan menyebabkan rata-rata konsumsi ransum harian pada itik menjadi menurun.

Hal ini sesuai dengan Marganov (2003), peningkatan kandungan serat kasar di dalam ransum akibat dari penambahan tepung karapas udang disebabkan oleh kandungan chitin yang cukup tinggi di dalam tepung karapas udang. Secara umum, karapas udang mengandung banyak zat chitin sekitar $15-20 \%$. Zat chitin tersebut berikatan dengan protein dan mineral pada ikatan kovalen $\beta$ (1-4) glukosida, sehingga sulit dicerna oleh pencernaan unggas. Hal ini mengakibatkan protein yang terdapat di dalam tepung karapas udang akan sulit terurai sehingga mengakibatkan semakin rendahnya konsumsi serta nutrisi yang terserap oleh saluran pencernaan ternak.

Shi-bin dan Hong (2012) yang mengamati efek suplementasi chitosan terhadap pertumbuhan dan indeks immune pada itik menggunakan ransum basal pada 7 level penambahan chitosan, yaitu $0,00 \mathrm{~g} / \mathrm{kg}, 0,30 \mathrm{~g} / \mathrm{kg}, 0,60 \mathrm{~g} / \mathrm{kg}, 1,20 \mathrm{~g} / \mathrm{kg}, 2,40 \mathrm{~g} / \mathrm{kg}, 4,80 \mathrm{~g} / \mathrm{kg}$ dan $9,60 \mathrm{~g} / \mathrm{kg}$ melaporkan adanya pengaruh penambahan chitosan di dalam ransum terhadap perbedaan rata-rata konsumsi harian itik. Pada penambahan chitosan 1,2g/kg ransum diperoleh rata-rata konsumsi harian 138,2g/ekor, sedangkan pada penambahan chitosan $2,4 \mathrm{~g} / \mathrm{kg}$ ransum diperoleh rata-rata konsumsi harian 129,08g. Dari perbedaan rata-rata konsumsi tersebut dapat disimpulkan bahwa terdapat suatu pengaruh yang sama. Semakin tinggi konsentrasi chitosan di dalam ransum, maka semakin rendah rata-rata konsumsi harian itik. Pada ransum perlakuan dengan suplementasi chitosan sebanyak $1,5 \mathrm{~g} / \mathrm{kg}$ di dalam ransum ternyata menghasilkan rata-rata konsumsi harian itik yang lebih rendah. Perbedaan ini disebabkan derajat deasetilasi chitosan yang digunakan dalam penelitian tersebut berbeda dengan penelitian yang dilakukan. 


\section{Pertambahan Bobot Badan (Average Weekly Body Gain/ AWG)}

Berdasarkan Tabel 2 rataan tertinggi AWG terdapat pada perlakuan T0 yaitu 120,63 gram/ekor; diikuti oleh perlakuan T1 yaitu 112.73 g/ekor; diikuti oleh perlakuan T3 yaitu 103,72 g/ekor; dan diikuti oleh perlakuan T2 yaitu 93,88 gram/ minggu.

Analisis ragam menunjukkan bahwa penambahan chitosan karapas udang di dalam ransum memberikan pengaruh yang berbeda nyata $(\mathrm{P}<0.05)$ terhadap AWG, sedangkan berdasarkan hasil uji jarak berganda Duncan (Duncan's Multiple Range Test) pada tingkat signifikan 5\%, T0 merupakan perlakuan dengan AWG tertinggi yang berbeda nyata $(\mathrm{P}<0.05)$ terhadap T1, T3 maupun T2.

Pada pembahasan sebelumnya mengenai pengaruh suplementasi chitosan terhadap jumlah konsumsi ransum, telah dijelaskan bahwa penambahan tepung karapas udang dan chitosan sebagai bentuk derivatnya di dalam ransum menyebabkan penurunan rata-rata jumlah ransum yang dikonsumsi oleh itik.

Perbedaan yang nyata $(\mathrm{P}<0.05)$ pada jumlah rata-rata konsumsi harian menyebabkan angka PBB pada itik juga menjadi sangat berbeda nyata $(\mathrm{P}>0.01)$. T0 dengan jumlah rata-rata konsumsi ransum tertinggi memiliki PBB yang lebih tinggi dibandingkan T1, demikian juga pada T1 dengan jumlah rata-rata konsumsi ransumnya lebih tinggi daripada T2 memiliki PBB yang lebih tinggi juga. Tren yang sama pada T3 hingga T2. Hal ini semakin mempertegas pendapat Marganov (2003) bahwa peningkatan kandungan serat kasar di dalam ransum akibat dari penambahan tepung karapas udang disebabkan oleh kandungan chitin yang cukup tinggi di dalamnya. Secara umum, karapas udang mengandung banyak zat chitin sekitar 15$20 \%$. Zat chitin tersebut berikatan dengan protein dan mineral pada ulit terurai sehingga mengakibatkan semakin rendahnya konsumsi ransum dan menyebabkan nutrisi yang terserap oleh saluran pencernaan ternak juga menjadi semakin rendah.

Hal ini juga sesuai dengan pernyataan Suhardi (1992) bahwa Senyawa chitin adalah suatu polimer golongan polisakarida yang tersusun atas satuan-satuan beta-(1 4)2asetamido-2-deoksi-D-glukosa, yang secara formalnya dapat dipertimbangkan sebagai senyawa turunan selulosa yang gugus hidroksil pada atom C2 digantikan oleh gugus asetamido Nama lain dari senyawa chitin adalah 2-asetamida-2-deoksi-D-glupinarosa (Apriani et al., 2012). Chitin termasuk ke dalam kelompok serat dari hewan yang memiliki struktur mirip selulosa dengan kadar total serat kasar $72.52 \%$ sehingga dikelompokkan ke dalam kadar serat sangat tinggi (Suryaningsih dan Parakkasi, 2006). Chitin dan chitosan memiliki struktur yang mirip dengan selulosa, perbedaannya terletak pada posisi C2 yang 
merupakan gugus asetamida pada chitin, sedangkan pada chitosan posisi C2 adalah gugus amina (Kim, 2011).

Nilai AWG yang diperoleh pada penelitian ini (93,89-120,63 g/ekor) ternyata jauh lebih tinggi dibandingkan dengan penelitian yang dilakukan oleh Shi-bin dan Hong (2012) juga tentang efek suplementasi chitosan terhadap performans pertumbuhan itik dengan AWG berkisar antara 56,43-65,63 g/ekor; namun lebih rendah dibandingkan dengan penelitian yang dilakukan oleh Muhammad et al. (2014) tentang pemberian ransum komplit berbasis bahan baku lokal fermentasi terhadap itik lokal Sumatera Selatan dengan AWG berkisar antara 100,76-218,48 g/ekor. Hal ini disebabkan kandungan serat pada ransum bersuplementasi chitosan jauh lebih tinggi dibandingkan pada ransum berbasis fermentasi. Demikian juga dengan chitosan, semakin tinggi kualitas chitosan, semakin tinggi serat kasarnya.

\section{Konversi Ransum atau Feed Conversion Ratio (FCR)}

Nilai FCR paling kecil terdapat pada T0, yaitu 7,70; diikuti oleh nilai FCR pada T1 yaitu 8,19; diikuti oleh nilai FCR pada T3 yaitu 8,88; dan diikuti oleh nilai FCR pada T2 yaitu 9,81 .

Analisis ragam menunjukkan bahwa penambahan chitosan derivat karapas udang di dalam ransum memberikan pengaruh yang berbeda sangat nyata $(\mathrm{P}<0.01)$ terhadap nilai FCR. Berdasarkan uji jarak berganda Duncan (Duncan's Multiple Range Test) pada tingkat signifikan 5\%, T2 menunjukkan nilai FCR yang tertinggi dibandingkan T0, T1 maupun T3.

Semakin kecil nilai konversi ransum, semakin efisien ransum yang digunakan; semakin besar nilai konversi ransum, semakin tidak efektif ransum yang digunakan. Dapat disimpulkan bahwa penambahan tepung karapas udang dan bentuk derivatifnya berupa chitosan di dalam ransum, walaupun tidak menunjukkan pengaruh yang buruk pada konsumsi ransum, namun penambahan tersebut memberikan pengaruh yang kurang baik pada konversi ransum. Artinya, dengan penambahan tepung karapas udang dan chitosan di dalam ransum, tingkat nutrisi yang dapat diserap oleh tubuh menjadi makin rendah. Hal ini sesuai dengan Anggorodi (1985) yang menyatakan bahwa konversi ransum merupakan indikator teknis yang dapat menggambarkan efisiensi penggunaan ransum. Angka konversi ransum akan membaik bila hubungan antara komposisi ransum telah disesuaikan. Faktor-faktor yang mempengaruhi konversi ransum adalah komposisi nutrisi ransum, bobot badan dan temperatur lingkungan. 
Nilai FCR yang diperoleh pada penelitian ini $(7,70-9,82)$ ternyata lebih tinggi dibandingkan penelitian yang dilakukan oleh Purba dan Ketaren (2011) dengan penambahan Santoquin dan Vitamin E pada berbagai level di dalam ransum diperoleh FCR berkisar antara 4,93-5,35; namun lebih rendah dibandingkan penelitian yang dilakukan oleh Shi-bin dan Hong (2012) tentang efek suplementasi chitosan terhadap pertumbuhan dan indeks immune pada itik, pada pemberian 1,2\% chitosan diperoleh FCR berkisar antara 11,02-12,17. Hal ini disebabkan kandungan serat pada ransum bersuplementasi chitosan jauh lebih tinggi dibandingkan pada ransum bersuplementasi santoquin dan Vitamin E. Demikian juga dengan chitosan, semakin tinggi kualitas chitosan, semakin tinggi serat kasarnya, semakin buruk efeknya terhadap FCR.

\section{Kadar Total Kolesterol Darah}

Hasil pengamatan kadar total kolesterol darah itik dilihat pada Tabel 3.

Tabel 3. Kadar total kolesterol darah (mg/ dL) pada itik lokal yang diberi ransum bersuplementasi chitosan selama 8 minggu penelitian.

\begin{tabular}{ccccccc}
\hline \multirow{2}{*}{ Perlakuan } & \multicolumn{5}{c}{ Ulangan } & \multirow{2}{*}{ Rataan \pm SD } \\
\cline { 2 - 5 } & 1 & 2 & 3 & 4 & 5 & \\
\hline T0 & 229 & 277 & 246 & 279 & 231 & $252,4^{\mathbf{a}} \pm 24,28$ \\
T1 & 247 & 233 & 214 & 203 & 223 & $224,0^{\mathbf{b}} \pm 16,97$ \\
T2 & 137 & 162 & 142 & 169 & 155 & $153,0^{\mathbf{d}} \pm 13,39$ \\
T3 & 178 & 188 & 195 & 194 & 172 & $185,4^{\mathbf{c}} \pm 10,08$ \\
\hline Ket : & \multicolumn{2}{l}{ angka yang diikuti oleh superskrip dengan notasi berbeda ke arah vertical menunjukkan perbedaan nyata pada uji } \\
\multicolumn{3}{l}{ Duncan (P<0.05). }
\end{tabular}

Tabel 3 menunjukkan bahwa rataan kadar total kolesterol tertinggi terdapat pada T0 sebesar 252,4 mg/dL; diikuti oleh T1 sebesar $224 \mathrm{mg} / \mathrm{dL}$; diikuti oleh T3 sebesar 185,4 $\mathrm{mg} / \mathrm{dL}$; dan diikuti oleh T2 sebesar $153 \mathrm{mg} / \mathrm{dL}$.

Analisis ragam menunjukkan bahwa penambahan chitosan di dalam ransum memberikan pengaruh yang sangat nyata $(\mathrm{P}<0.01)$ terhadap kadar total kolesterol darah pada itik, sedangkan berdasarkan hasil uji jarak berganda Duncan (Duncan's Multiple Range Test) pada tingkat signifikan 5\%, T2 merupakan perlakuan terbaik yang paling efektif menurunkan kadar total kolesterol darah dibandingkan T0, T1 maupun T3.

Rataan kadar total kolesterol yang diberi suplementasi chitosan berkisar antara 252,4153,0 mg/dL yang cenderung menurun dibandingkan dengan kontrol seiring perbedaan chitosan yang diberikan. Hal ini dikarenakan chitosan memiliki gugus amina bebas bermuatan positif yang terbentuk melalui proses deasetilasi sehingga dapat mengikat asam empedu yang bermuatan negatif sebagai hasil utama biosintesa kolesterol dan membuangnya 
sebagai massa feses sehingga mengurangi kadar total kolesterol dalam darah. Hal ini sesuai pernyataan Goodman (2000) bahwa jumlah kolesterol dalam sel ditentukan oleh interaksi 4 faktor, yakni laju pembuatan kolesterol oleh hati dari asetat, laju kolesterol diperoleh dari makanan, laju kolesterol yang diubah ke asam empedu dan dibuang melalui usus halus serta laju asam empedu yang diserap kembali dan diubah menjadi kolesterol.

Penurunan kadar total kolesterol terjadi baik pada T1, T2 maupun T3, namun pada tingkat keefektifan yang berbeda. Hal ini dikarenakan konsentrasi 1,5 g chitosan yang diberikan sebagai bentuk murni hasil ekstraksi menjadi lebih tinggi dibandingkan jika diberi dalam bentuk karapas udang. Kadar 1,5 g chitosan yang terdapat pada karapas yang belum mengalami pemurnian masih berikatan dengan komponen penyusun karapas udang lainnya, sehingga jumlah gugus asetil yang digantikan oleh gugus amina bebas belum maksimal. Hal ini terlihat jelas dari rataan kadar total kolesterol yang dihasilkan. Perlakuan T2 dengan penambahan 1,5\% chitosan derivat karapas udang menghasilkan kadar total kolesterol darah yang nyata lebih rendah $(\mathrm{P}<0.05)$ dibandingkan T0, T1 dan T3.

Hal ini sesuai pernyataan Purnamawati (1997) yang menyatakan bahwa chitin mampu menurunkan absorbsi kolesterol lebih efektif daripada selulosa dan mempunyai potensi sebagai hipokolesterolemik yang tinggi serta digesti dan absorbsi lemak dalam traktus intestinal berinteraksi dengan pembentukan misela atau emulsifikasi lipid pada fase absorbsi (Deuchi et al., 1994).

Dibandingkan dengan penelitian oleh Pagala dan Nur (2010) tentang pengaruh chitosan asal cangkang udang terhadap kadar lemak dan kolesterol darah itik menggunakan ransum basal jenis RK-24-AA dengan penambahan berbagai level chitosan yaitu $0 \%, 0,5 \%$, $1,0 \%$ dan 1,5\% melaporkan bahwa kelompok ternak yang ransumnya disuplementasi dengan 1,5\% chitosan memiliki kadar total kolesterol darah $134,87 \mathrm{mg} / \mathrm{dL}$. Ternyata penambahan 1,5 $\mathrm{g} / \mathrm{kg}$ chitosan asal karapas udang yang dilakukan dalam penelitian terhadap T2 menghasilkan kadar total kolesterol dengan angka yang lebih tinggi yaitu 153,6 mg/dL, namun secara keseluruhan persentase penurunan kadar total kolesterol terhadap perlakuan kontrol pada penelitian yang dilakukan adalah lebih efektif dibandingkan penelitian tersebut. 


\section{KESIMPULAN}

Suplementasi tepung karapas udang, chitosan derivat karapas udang maupun chitosan komersial di dalam ransum dapat menurunkan kadar total kolesterol darah dan performans itik (P<0.05). Total kolesterol darah (mg/dL) pada T1; T2: T3; T4 adalah 252,4; 224,0; 153,0; 185,4. Sedangkan rata-rata pertambahan bobot badan menurun 6,55\%; 22,18\%; dan $14,02 \%$ dibandingkan terhadap perlakuan kontrol. Hasil terbaik diperoleh pada suplementasi $1,5 \%$ chitosan derivat karapas udang.

Penambahan chitosan di dalam ransum itik secara ekonomi merugikan karena mengurangi efisiensi ransum, namun dari segi kesehatan dapat mengurangi resiko hiperkolesterolemia, sehingga penambahan chitosan sebaiknya hanya dilakukan untuk tujuan kesehatan saja.

\section{DAFTAR PUSTAKA}

Anggorodi, R. 1985. Kemajuan Mutakhir dalam Ilmu Makanan Ternak Unggas. Unversitas Indonesia Press, Jakarta.

Apriani L., Iskandar M. G., dan M. Said, 2012. Pengaruh Variasi Konsentrasi NaOH Terhadap Nilai Derajat Deasetilasi Pada Pembuatan Chitosan Dari Cangkang Kulit Kepiting. Jurusan Teknik Kimia Fakultas Teknik Universitas Sriwijaya. Palembang. Junal Teknik Kimia, Vol. 18 (1):35-40

Ariyani, E., 2006. Penetapan Kandungan Kolesterol dalam Kuning Telur Pada Ayam Petelur. Balai Penelitian Ternak. Bogor. Temu Teknis Tenaga Fungsional Pertanian.

Bakrie, E., Manshur, E., dan Sukadana, I. M., 2012. Pemberian Berbagai Level Tepung Cangkang Udang Ke Dalam Ransum Anak Puyuh Dalam Masa Pertumbuhan (Umur 1-6 Minggu). Provision of Various Levels of Shrimp Shells Into Flour Rations Quail In Growing Child (Age 1-6 Weeks. Jurnal Penelitian Pertanian Terapan Vol. 12 (1): $58-68$

Dedi R., dan Rachmat Wiradimaja, 2011. Pendugaan Kadar Kolesterol Daging dan Telur Berdasarkan Kadar Kolesterol Darah pada Puyuh Jepang [Estimated Cholesterol Levels of Meat and Egg Based on Blood Cholesterol on the Japanese Quail]. Fakultas Peternakan Universitas Padjajaran. Bandung. Jurnal Ilmu Ternak Vol. II (1):35-38

Deuchi, K., Kanauchi, O., Imasoto, Y., Kobayashi, E., 1994. Decreasing effect of Chitosan on the Apparent Fat Digestibility by Fats of a High Fat Diet. Biosci. Biotech. Biochem. 58:1613-1616

Goodman, K., 2000. Biotechnology in the Marine Sciences. Wiley \& Sons, Inc. Canada. 
Kim, Seo Won, 2011. Chitin, Chitosan, Oligosaccharides and Their Derivatives. Ebook. USA: CRC Press

Marganov, A.M., 2003. Potensi Limbah Udang sebagai Penyerap Logam Berat (Timbal, Kadmium dan Tembaga) di Perairan. http:rudyct.topcities.com/ 10 November 2015

Muhammad N., Sahara E., Sandi S., dan Yosi F., 2014. Pemberian Ransum Komplit Berbasis Bahan Baku Lokal Fermentasi terhadap Konsumsi, PertambahanBobot Badan, dan Berat Telur Itik Lokal Sumatera Utara. Program Studi Peternakan Fakultas Pertanian Universitas Sriwijaya. Jurnal Peternakan Sriwijaya Vol. 3 (2):20-27

Pagala, A. M. dan Nur Indrayani, 2010. Pengaruh Chitosan Asal Cangkang Udang Terhadap Kadar Lemak dan Kadar Kolesterol Darah Itik. Jurusan Peternakan Fakultas Pertanian Universitas Haluoleo. Kendari. WARTA-WIPTE, Vol. 18 (01):26-31

Purba M., dan Pius P. Ketaren., 2011. Konsumsi dan Konversi Pakan Itik Lokal Jantan Umur Delapan Minggu dengan Penambahan Santoquin dan Vitamin E dalam Pakan [Feed Consumption and Feed Conversion Ratio of Eight Weeks Old Male Local Ducks Treated with Santoquin and Vitamin E Supplement]. Balai Penelitian Ternak. Bogor. JITV Vol. 16 (4):280-287

Purnamawati, D. 1997. Pemanfaatan Khitosan Udang Windu (Panaeus monodon) dalam Minuman Kaya Serat Makanan. Skripsi. Jurusan Teknologi Pangan dan Gizi, Fakultas Teknologi Pertanian. IPB. Bogor

Saidin, M., 2000. Kandungan Kolesterol Dalam Berbagai Baha Makanan Hewani. Pusat Penelitian dan Pengembangan Gizi. Badan Penelitian dan Pengembangan Kesehatan. Departemen Kesehatan RI. Buletin Penelitian Kesehatan, Vol. 27 (2):224-230

Shi-bin Y. dan Chen H., 2012. Effects of Dietary Supplementation of Chitosan on Growth Performance and Immune Index in Duck. Institute of Rare Animals and Plants. College of Life Science. China west Normal University. Sichuan. College of Animal Science and Technology. Shihezi University. Xinjiang. P. R. China. Afican Journal of Biotechnology,

Vol. 11 (14): 3490-3495

Suhardi, 1992. Khitin dan Khitosan. Pusat Antar Universitas Pangan dan Gizi UGM, Yogyakarta.

Suryaningsih. L., dan Parakkasi. A., 2006. Pengaruh Pemberian Tepung Cangkang Udang (Karapas) sebagai Sumber Khitin dalam Ransum Terhadap Kadar LDL (Low Density Lipoprotein), HDL (High Density Lipoprotein) dan Persentase Karkas [Effects of Shrimp Shell Mills as Chitin Source on LDL (Low Density Lipoprotein), HDL (High Density Lipoprotein) of Meat and Carcass Percentage]. Jurnal Ilmu Ternak, Vol. $6(1): 63-67$

Tjay, Tan Hoan and Kirana Rahardja, 2007. Obat-obat Penting: Khasiat, Penggunaan dan Efek-efek Sampingnya. PT Elex Media Komputindo Kelompok Kompas-Gramedia. Jakarta. 